\title{
GLOBAL E-TRENDS IN RUSSIAN HIGH EDUCATION SYSTEM AS ESSENTIAL TOOLS OF ITS CHANGE MANAGEMENT
}

\author{
Anna Zotova ${ }^{1, \mathrm{a},{ }^{*}, \text { Valentina Mantoulenko }}{ }^{2, \mathrm{~b}}$ and Kirill Primaka ${ }^{3, \mathrm{c}}$ \\ ${ }^{1}$ Samara State University of Economics, Chair of Applied Management, Russia, 443090, Samara, \\ Sovetskoi Armii Street,141, Room 309 \\ ${ }^{2}$ Samara State University of Economics, Chair of Applied Management, Russia, 443090, Samara, \\ Sovetskoi Armii Street,141, Room 309 \\ ${ }^{3}$ Samara State University of Economics, Chair of Applied Management, Russia, 443090, Samara, \\ Sovetskoi Armii Street,141, Room 309 \\ aazotova@mail.ru, ${ }^{b}$ mantoulenko@mail.ru, cprimakakirill@gmail.com. \\ *Corresponding author
}

Cite as: Zotova, A., Mantoulenko, V, Primaka, K. (2018). Global E-trends in Russian high education system as essential tools of its change management, Ekonomicko-manazerske spektrum, 12(1), 94-103.

Available at: dx.doi.org/10.26552/ems.2018.1.94-103

\begin{abstract}
Modern "post-industrial" era is distinguished by such rapid global changes and almost instantaneous copying of products and services that make it meaningless reaching the goal of long-term retention of a certain market position. Constant perfection of design and service accompanying provision of products and services, is becoming a condition for successful business development. The strategy ceased to be only a long-term plan and was formed as the concept of a management process which is characterized by a constant adjustment in the on-line regime. Today, the educational community is also subjected to these changes. The need for changes and adaptation to an ever-changing environment poses a number of new challenges for educational institutions aimed at training specialists with a set of core competencies for the information society. Universities today are doing their best to attract international students. They are mobile young people (there are more than 5 million people in the world), possessing great abilities. The war for talent leads to the rapid differentiation of educational institutions. Technological innovations came with a delay of about 10 years in the sphere of education. Today, the annual growth of the online education market is $27 \%$, the traditional - 5\%. In 2016, more than 50 million people around the world studied using the largest online platforms. So the main task of this research work is to define the influence of some educational global trends on Russian education system (regarding these trends as important tools of change management for educational institutions) and assess the readiness of Russian universities to such influence.
\end{abstract}

Keywords: global educational trends, universities, e-learning

JEL Classification: F69

\section{Introduction}

Modern "post-industrial" era is distinguished by such rapid global changes and almost instantaneous copying of products and services that make it meaningless reaching the goal of long-term retention of a certain market position. The strategy ceased to be only a long-term 
plan and was formed as the concept of a management process which is characterized by a constant adjustment in the on-line regime. Today, the educational community is also subjected to these changes. Universities today are doing their best to attract international students. They are mobile young people (there are more than 5 million people in the world), possessing great abilities. The war for talent leads to the rapid differentiation of educational institutions. Technological innovations came with a delay of about 10 years in the sphere of education. Modern technical means play big role in our every year life and in the educational process. Ditital technologies influense the higher education in many ways setting as well new opportunities as new challenges for its development (Pons, Juan de Pablos, 2018) and often determining the quality of educational services (Seyfried, M. et. al. 2018). The media-tools are a useful educational technology thanks to their inherent qualities of interactivity, flexibility and integration of different types of educational information, as well as due to the possibility to take into account individual characteristics of learners and to increase their motivation and cognitive activity, in accordance with Abeldina et al. (2015), Acar et al. (2008). Modern information technologies are the basis of informatization processes in the educational sphere, the implementation of which involves:

- improving the quality of education through the more effective use of available information; increasing the effectiveness of the educational process on the basis of its diversification and intensification;

- usage of means, methods and technologies with a focus on developing, advanced and personal-oriented education;

- achievement of the necessary level of professionalism in media using;

- integration of various types of activities (educational, research, methodological, scientific, organizational) within the framework of a unified methodology, based on the application of information technologies;

- training participants in the educational process for life in the information society;

- increase of professional competence and competitiveness;

- the ability of future specialists in various industries;

- overcoming the crisis phenomena in the education system (Goryachev et al.,2014).

All these aspects influence as well the quality of education as the readiness of organizations to change, in accordance with Olguin (2016), and Sheiladevi (2016). Use of new information technologies in education is becoming increasingly a widespread phenomenon in the modern Russian education. The universities introduce different online platforms (for example, Moodle, Joomla, Edmodo, Blackboard) for the development of educational communications between students and teachers. As a rule, materials, generated on these resources are positioned as educational or educational potential, but often they do not possess these qualities, according to Adelabu et al. (2014), Aggarwal et al. (2009), and Ali \& Magalhaes (2008). A lot of Russian universities don't have any information strategy while the sustainable development of modern higher education institutions is not conceivable without information management, argued by Codutti et. al. (2017), and Aleixo et. al. (2018).

Today, the annual growth of the online education market is $27 \%$, the traditional - $5 \%$. In 2016, more than 50 million people around the world studied using the largest online platforms. The appearance in the early 2000s of international university rankings (ARWU, QS, THE) gave us the opportunity to compare universities of different countries, which was the beginning of global competition era. The ratings have launched new mechanisms for the redistribution of resources in education: leaders strengthen their reputation, receive funding. Academic mobility is also in the best hands: according to research, masters, graduate students and professors today choose universities on the basis of international ratings. The wall has 
grown between high schools of the top 100 and all the others and this inequality will grow rapidly with each passing year. As a result, a country that does not have universities in a group of leaders, in the long term, 5-10 years, risks losing competition for intellectual capital and becoming an educational province (The report, 2010).

There are many high schools in the Russian Federation, but only few of them show successful development and provide students with high quality of educational services. To maintain sustaining growth these organizations, have to be flexible and ready for change. The readiness to changes is a key feature of the modern business in the conditions of innovative and electronic economy. For the Russian market, as part of the global economy, this phenomenon is relevant too, and it requires some fresh thinking and changes for the traditional approach to management.

\section{Methodology}

The methods for the research are systems analysis and methods of expert judgments. Stages of the research work:

- the first stage was implemented through theoretical analysis of e-trends stimulating education system changes and intellectual capital development is performed;

- the second stage was performed through monitoring and analytical research work aimed at studying distance learning development in high education system of Samara region and its perspectives.

\section{Results}

\subsection{The analysis of e-trends stimulating education system changes and intellectual capital development is performed}

In the sphere of education, technological innovations came with delay of about 10 years. The first online projects here appeared in the 1990s and were associated with the transfer of electronic materials to educational materials, by Neisbitt (1990). True, they did not have a serious impact on the industry. In 2011, second-generation projects appeared on the market mass open online courses (Massive Open Online Courses, or MOOC). It is believed that it was the point from which the digital revolution began in education. Today, the annual growth of the online education market is $27 \%$, the traditional - 5\%. In 2016, more than 50 million people around the world studied using the largest online platforms (EdX, Coursera, Udacity, etc.), 800 thousand of them are Russians. In addition to private projects, a number of states launched their own national platforms - the United Kingdom, Australia, Brazil, and Russia joined to the countries in 2015 .

The main innovation of such platforms is the design of the courses: they consist of small video fragments for 5-10 minutes, due to which the listeners kept concentration. 2015 was a new milestone in the development of digital education. LinkedIn for $\$ 1.5$ billion bought the project Lynda.com, which revised the training process. The basis of the program was not mini-lectures, but tutorials, short video instructions for representatives of different professions. For several years, the world's leading experts have created more than 25 thousand tutorials, and for access to them it is enough to buy a monthly, semi-annual or annual subscription. There was a new type of educational project - a kind of "intellectual fitness room", where at any time you can buy a ticket.

The development of information technology entailed a boom of educational startups. 
Since the beginning of the 2000s, a new class of projects has appeared in the field of education. For the first time significant financial resources were attracted not by universities with their centuries of history and brand, but young teams of entrepreneurs. Ten years ago, the global volume of venture investments in educational startups barely reached \$ 100 million, and in 2016 it exceeded $\$ 3$ billion, which is comparable to the annual costs of education of individual countries. Profiles of educational startups are diverse. For example, the most successful start-up, attracted more than \$300 million, - TutorGroup - teaches English on the Internet. And the project Achieve3000, which collected a quarter of a billion dollars, develops the ability to read and understand the text. One of the most vivid examples of the new era is the Minerva program, which claims to train world leaders and innovators of the future. Its founders managed to attract more than $\$ 25$ million at the idea stage.

All new educational projects unite one thing - they are built on modern technologies, use a synthesis of advanced developments in the field of computer intelligence, digital technologies and behavioral psychology. The best educational startups already compete with traditional universities for their investments and talents, argued by Lee et. al. (2018). Over the last 5 years appeared many companies using AI and Machine Learning to improve educational process. Especially in following sectors:

- Grading automation (ClassroomIQ, Mimir),

- Prediction the behavior of the students (to prevent an increase in dropout rates at MOOC and real schools),

- Personalization education programs (Area9, Aleks, Knewton, Tabtor, CogBooks,Cognii, Infantium),

- AI-powered writing assistants,

- Other sectors like dynamic scheduling, matching teachers and schools.

But the best results were demonstrated by companies using AI and ML to create personalization algorithms for education process because society and business understand "one-for-all" educational programs doesn't work because of the difference in mental development both sectors have a demand for such technologies. Integrating such systems with intelligent and adaptive systems that can measure the learning preferences of the user can enable learners to obtain the most suitable learning objects that might be matched with their learning styles. Moreover, even in the classroom teaching, knowing the learning styles of students can also help teachers to adopt appropriate learning materials for efficient learning, stated by Hamada \& Hassan (2017), and Mooney et. al. (2014). Such system exploits the modularity of digital content to serve individual learners with content personalized to their learning style and help teachers to track progress and efficiently allocate time and determine teaching approach. More complex systems offer not only personalization but also macro analytics to learn the best methods of teaching certain concepts for learners of different types that can be applied more broadly than an individual piece of content or course.

Table 1: E- trends and their influence on high education system, authors' development.

\begin{tabular}{ll}
$\begin{array}{l}\text { Global e-trends, } \\
\text { influencing all human } \\
\text { sphere Neisbitt(1990); }\end{array}$ & $\begin{array}{l}\text { Trends, influencing } \\
\text { education system }\end{array}$ \\
$\begin{array}{l}\text { Shakleina \& Baikova } \\
(2014)\end{array}$ & \\
\hline $\begin{array}{l}\text { 1. Information } \\
\text { technologies } \\
\text { development }\end{array}$ & Education virtualization \\
\end{tabular}

Global e-trends, influencing all human sphere Neisbitt(1990) Shakleina \& Baikova (2014)

technologies

development

First level reaction (the result, which is the output of trend influence on education system)

Emergence and development of new forms and approaches to education based on modern technologies usage
Second level reaction (the reaction on the first level result)
New approaches to distance education implementation

Education quality decrease; 


\begin{tabular}{lll} 
& \multicolumn{1}{c}{$\begin{array}{l}\text { Competition growth in the } \\
\text { sphere of virtual (distance) } \\
\text { education. }\end{array}$} & \\
$\begin{array}{l}\text { Personification, } \\
\text { individualization }\end{array}$ & $\begin{array}{l}\text { E-learning education } \\
\text { technology popularization, } \\
\text { teaching on-line. }\end{array}$ & $\begin{array}{l}\text { Growth in the gap in the } \\
\text { quality of students' } \\
\text { education; }\end{array}$ \\
Gamefication & $\begin{array}{l}\text { Growth of education } \\
\text { projects based on } \\
\text { gamefication elements. }\end{array}$ & $\begin{array}{l}\text { Emergence of new } \\
\text { education programs based } \\
\text { on gamefication. }\end{array}$ \\
New competences \\
development among the \\
students
\end{tabular}

Source: author's compilation in accordance with Neisbitt (1990); Shakleina \& Baikova (2014)

New technologies are causing "industrial revolutions" that change the work of companies. Business dictates new requirements to people's competencies and the speed at which they are received. There is a number of "retired professions" leaving the market. The most striking example of recent years is the massive bankruptcies of travel agencies, losing competition to services like Booking.com or Airbnb. At the same time, thanks to new technologies, the professions of the future appear, in which intellectual skills and qualities, which help to make non-standard decisions, are in demand (Shakleina, T.A., et. al., 2014).

Today it is already impossible to build a successful professional trajectory for years to come, but the traditional education system is based on the principle of long-term planning. The list of the most popular competences will be updated more often. If earlier a new profession arose once in 20-30 years, today it is every 3-5 years. The ability of the education system to respond quickly to new requests, to train specialists not for 5 years, but for 5 months, becomes a condition for the country's competitiveness. To this challenge, most educational institutions in the world have only to find an answer in Khasaev \& Ashmarina (2014).

\subsection{The analysis of distance learning development in high education system of Samara region}

The most modern trend in the development of modern higher education is the promotion of distance learning and the gradual replacement of education by distance education. To effectively promote the distance education system, the development of information and communication technologies is vital. The authors of this work analyzed distance learning technologies in the leading universities of the Samara region.

The results of the authors' research showed that a number of Samara higher educational institutions have already demonstrated high readiness for the projected changes and are actively implementing information and communication technologies. The largest number of areas covered by distance education is shown by the Samara State Technical University. Individual universities are still lagging far behind in promoting distance education with the help of modern technologies. Samara State Economic University launched the site "Virtual Campus", but so far only for students of the Master degree faculty. This site was organized on the basis of the MOODLE platform, which is a content management system (CMS), specifically designed to create qualitative online courses by teachers. 
The effective organization of undergraduates independent work is proposed to be done through the use of information and communication technologies. New means of communication allow the teacher to communicate with students on a flexible schedule through teleconferences, blog, e-mail. These technologies also provide an opportunity to carry out individual control over the training, the teacher has the opportunity to observe the progress, the time of assignments and the pace of work of individual students. This makes it possible to build a specific schedule for students, and to consult each student individually. On the other hand, students also have the opportunity to monitor their academic performance and correct their results on time, argued by Davies \& Graff (2005), and Cheung \& Vogel (2013).

In fact, the term "virtual campus" first appeared in Europe around the mid-1990s. It was introduced in national programs and strategic documents of the European Commission. More than 10 years ago, European politicians began to stimulate an analysis of the potential of ICTs to improve the quality of education in higher education system. The European Commission's strategic reports pointed to the fact that "new technologies" are of strategic importance for the creation of "universities of the future". The direct result of these reports was a small number of projects aimed at exploring the possibility of creating virtual universities in Europe.

In the "Peer Review" handbook, which was conducted in 2005-2007 in the "MASSIVE" project (Modelling Advice and Support Services to Integrate the Virtual Component in Higher Education), a model of necessary measures was proposed to implement the virtual components of education in traditional European universities. What also was a historical milestone in the formation of such a concept of "virtual campus".

Although the age of the term "virtual campus" is 15 or so years old, it is still in its infancy, and changes very quickly. Over the years, observers have noticed a shift in concepts: from "clearly", openly, $100 \%$ online virtual campus, to virtual, in terms of mobility, and in some ways, as a way for traditional universities to open their borders, to cooperate (inter) And / or attract non-traditional students through e-learning. It should be noted that the "Mixed Model" of training arouses more and more interest and attention in Europe. In this connection, the authors propose the following formulation of the term "virtual campus - an information and communication environment for supporting the learning process and ensuring interaction between students and teachers", which meets modern conditions.

Web2 tools allow you to generate multi-user content. This allows develop and use training courses collectively. Information and communication technologies make it possible to use various didactic approaches. There is an opportunity to include audio or video lectures, various graphics in the course.

Such learning strategies can be implemented using e-learning tools. That is why it is actual to create a virtual campus of master's programs, which allows to use educational content effectively. As a result of the research, the greatest activity of non-state educational institutions and branches in the promotion of their distance programs was revealed. These educational institutions quite reasonably seek to occupy that segment of the market of educational services, which is not yet being interested too much by the key universities in the region. So in the Samara branch of the Moscow City Pedagogical University, the specialized structural subdivision - the center for distance learning was allocated. Also, a program was developed to implement distance learning based on the distance education system "Prometheus".

In addition to the MOODLE platform, Samara State University made some attempts in using the platform Edmodo working out special educational cources for extramural students based on involving social media into the university training process. Parusheva et al. (2018), and Tong et al. (2014) state, that studying the perspectives of using social networks in the 
higher education, the researches emphasize some advantages and disadvantages of these resources for the educational proces. Among positive aspects are mobility and efficiency, technological adaptability, recognizability, the difference in the methodology of the teachers' work from the traditional, familiar, well-known communication environment for students, accessibility, interaction, etc.

On the other hand, the use of social networks in the university educational process has a number of difficulties: the lack of a developed concept and scientific and methodological support for the effective application of these technologies in the learning process; lack of access to social networks from the university's classrooms as a result of their blocking or lack of necessary technical support, as well as a large amount of entertainment content, distracting from training activities, psychological barriers, etc. Stated by Goryachev et al. (2014), and Selim (2007). An analysis of the results of studies on the use of information and communication technologies in higher education suggests that there are no general concepts that would allow us to capture and present a multitude of facts accumulated in the practice of education and upbringing in a single system of concepts. The analysis of practice also allows us to conclude that there is an underestimation of the possibilities of ICT in the sphere of domestic higher education. This is primarily due to the complexity and low readiness of higher education institutions to introduce and use information and communication technologies in their activities.

\section{Discussion}

Monitoring of innovative behavior of the Russian population, organized by the researchers of the Higher School of Economics, Sobolevskaya (2014) states, with the aim of identifying channels of life-long-education, showed that in 12 percent of cases receiving new knowledge was realized through using at least one of the Internet services. This figure is twelve times greater than that was registered in 2006. Based on these monitoring data, scientists identify forms of obtaining new information - from communication on thematic sites to participation in distance seminars, webinars, listening to audiolections, watching videos.

However, the above analyst does not provide answers to the following questions. Is the received information a kind of knowledge that can be used in the future? Is online learning really a learning process as an independent form of study? What are its characteristics, properties and differences from the "classical" form of the knowledge acquisition? Furthermore, the authors of the studies, e.g. Al-Alak \& Alnawas (2011), and Sun et al. (2008) note that during their scientific work they were focused on self-education, where the knowledge acquisition is usually not accompanied by a certification and compulsory educational programs.

The study of the online technologies application in higher education in the classroom and in a distant form Graham et al. (2010) shows that for the changing the traditional learning process organization, in addition to development of an activity plan, it is necessary to involve additional resources and knowledge. That means regulation of such aspects as communication time, rules for building communication in the network, formation of additional types of interactions between students, online and offline, defining the roles between instructor and teacher. The processes presented in a concentrated form by offline learning - mastering knowledge, working out skills, the consolidation of skills, the formation of motivation, monitoring, verification and evaluation of training - hardly reflect in the aggregate in an online environment, stated by Luo et al. (2017). A significant research problem in the study of e-learning projects is the development of training courses programs with optimal distribution 
of time management, online and offline regulation of interaction forms, training and adequate knowledge assessment, based on Bajenaru (2012), and Krakowska (2007).

\section{Conclusion}

Many e-learning experts are against narrow understanding of informatization in the educational sphere, making a bet not on auto-training management systems, universal tools for preparation of training content, educational and testing materials, collection of information about students' progress and others, but also on social networks. These resources are considered as means for building own training or working space expanding opportunities for joint work of participants in the educational process.

Sobolevskaya (2014) and Pinho et al. (2018) argue, synthesis of "classical", classroom forms of teaching and modern computer technologies, clear determination of the target students group (for example, correspondence students, students with disabilities) create conditions for using electronic programs and online resources in the professional education. The use of information and communication technologies as additional means of learning, organizational forms of the education process creates conditions for the modernization of the Russian higher school education, providing its accessibility, democracy, the high quality of the academic preparation of future bachelor students, master students and specialists.

During this research work some new aspects and problems were discovered which need to be studied. Analysis of pedagogical theory and real educational practice allowed us to distinguish the existing contradictions in the investigated area:

- between the increasing information flow received by students in the university, the presence of problems related to its search, work, reproduction, and the unwillingness of students to resolve these problems, work with different information flows, manage them, use information skillfully;

- between modern requirements to the media competence of specialists (possession of various types and sources of information, including media, a new style of thinking, information immunity, the ability to extract personal meanings of information, assess it critically, etc.) and insufficient attention to these requirements in the process of higher school education;

- between the integrative nature of media culture and the scattered, fragmentary character of its formation in the university;

- between the high need for self-development of students' media culture and their lack of readiness for its self-development.

\section{Acknowledgment}

The research is done in the frame of the state task of the Ministry of Education and Science of the Russian Federation №26.9402017/PC "Change management in high education system on the basis of sustainable development and interest agreement".

\section{References}

Abeldina, Z., Moldumarova, Z., Abeldina, R. \& Moldumarova, Z.I. (2015). Virtual Learning Space in the System of E-Learning. Mediterranean Journal of Social Sciences, 6(5), 478-483.

Acar, E., Wall, J., McNamee, F., Carney, M. \& Öney-Yazici, E. (2008). Innovative Safety Management Training Through E-Learning. Architectural Engineering and Design Management, 4(3-4), 239-250.

Adelabu, O.A., Adu, E.O. \& Adjogri, S.J. (2014). The Availability and Utilization of E-Learning Infrastructures for Teaching and Learning. Mediterranean Journal of Social Sciences, 5(23), 1348-1355. 
Aggarwal, A.K. \& Makkonen, P. (2009). Critical Success Factors for Successful Globalised E-Learning. International Journal of Innovation and Learning, 6(1), 92-109.

Al-Alak, B.A. \& Alnawas, I.A.M. (2011). Measuring the Acceptance and Adoption of E-Learning by Academic Staff. Knowledge Management and E-Learning, 3(2), 201-221.

Aleixo, A.M., Leal, S. \& Azeiteiro, U.M. (2018). Conceptualization of Sustainable Higher Education Institutions, Roles, Barriers, and Challenges for Sustainability: An Exploratory Study in Portugal. Journal of Cleaner Production, 172, 1664-1673.

Ali, G.E. \& Magalhaes, R. (2008). Barriers to Implementing E-Learning: A Kuwaiti Case Study. International Journal of Training and Development, 12(1), 36-53.

Bajenaru, G.C. (2012). Pedagogical Challenges in Designing E-Learning Programs in The Xxist Century. Quality - Access to Success, 13(SUPPL.3), 711-714.

Cheung, R. \& Vogel, D. (2013). Predicting User Acceptance of Collaborative Technologies: An Extension of the Technology Acceptance Model for E-Learning. Computers \& Education, 63, 160-175.

Davies, J. \& Graff, M. (2005). Performance in E-Learning: Online Participation and Student Grades. British Journal of Educational Technology, 5(4), 657-663.

Codutti, C.A.E,. Marino, S.I., Alfonzo, P.L. (2017). Information Management in Higher Education. An Experience of Changes in Software Evolution Applied to Content Management Systems. IJERI International Journal of Educational Research and Innovation, 8, 293-304.

Goryachev, M.D., Goryachev, M.M., Ivanushkina, N.V. \& Mantoulenko, V.V. (2014). Net Resources Usage in Modern Education. Samara University Journal, 5(116), 220-227.

Graham, C.R., Hilton, J., Rich, P. \& Wiley, D. (2010). Using Online Technologies to Extend a Classroom to Learners at a Distance. Distance Education, 31(1), 77-92.

Hamada, M. \& Hassan, M. (2010). An Enhanced Learning Style Index: Implementation and Integration into an Intelligent and Adaptive E-Learning System. Eurasia Journal of Mathematics Science and Technology Education, 13(8), 4449-4470.

Luo, N., Zhang, M. \& Qi, D. (2017). Effects of Different Interactions on Students' Sense of Community in ELearning Environment. Computers \& Education, 115, 153-160.

Khasaev, G.R. \& Ahmarina, S.I. (2014). Main Trends and Perspectives of Heis Competitiveness Improvement. Vestnik SSEU, 8(118), 62-65.

Krakowska, M. (2007). New Forms of Electronic Tools in the Information and Communication Used for Creating the European Higher Education Area and E-Learning Development. Proceedings of International Multi-Conference on Society, Cybernetics and Informatics. Orlando, Florida: 240-245.

Lee, M.T. \& Raschke, R.L. (2018). Freeing "Workplace Prisoners" in Higher Education: Configurations for Collective Knowledge Building and Educational Value Decisions. Journal of Business Research, 88, 443448.

Mooney, J.S. Cappelli, T., Byrne-Davis, L. \& Lumsden C.J. (2014). How We Developed Eforms: An Electronic Form and Data Capture Tool to Support Assessment in Mobile Medical Education. Medical Teacher, 36(12), 1032-1037.

Neisbitt, J. (1990). Megatrends 2000. Ten New Directions for the 1990s. William \& Morrow Company, Inc.

Olguin, Ed. \& Caro, Fr. (2016). Change Management and Innovation in Engineer Education. Proceeding of the 8th International Conference on Education and New Learning. Barcelona, Spain: 3051-3057.

Parusheva, S., Aleksandrova, Ya. \& Hadzhikolev, A. (2018). Use of Social Media in Higher Education Institutions - An Empirical Study Based on Bulgarian Learning Experience. TEM Journal - Technology Education Management Informatics, 7(1), 171-181.

Pinho, Cl., Franco, M. \& Mendes, L. (2018). Web Portals As Tools to Support Information Management in Higher Education Institutions: A Systematic Literature Review. International Journal of Information Management, 41, 80-92.

Pons, J. de P. (2018). Digital Technologies and Their Impact on Higher Education. The New Mediations. RiedRevista Iberoamericana de Educacion a Distancia. 21(2), 83-95.

Selim, H.M. (2007). Critical Success Factors for E-Learning Acceptance: Confirmatory Factor Models. Computers \& Education, 49(2), 396-413.

Seyfried, M. \& Ansmann, M. (2018). Unfreezing Higher Education Institutions? Understanding the Introduction of Quality Management in Teaching and Learning in Germany. Higher Education, 75, (6), 1061-1076.

Shakleina, T.A. \& Baikova, A.A. (2014). Megatrends. Main Evolution Trends of Global Character in XXI Century. Moscow, Russia: Aspekt Press.

Sheiladevi, S. \& Rahman, A. (2016). Investigation on Impact of E-Learning Implementation on Change Management in Malaysian Private Higher Education Institutions. Pertanika Journal of Science and Technology, 24(2), 517-530. 
Sobolevskaya, O.V. (2014). The Internet is the Main Assistant in Self-Education Process. [Online]. Available: http://www.opec.ru/1715182.html.

Sun, P.C., Tsai, R.J., Finger, G., Chen, Y.Y. \& Yeh, D. (2008). What Drives a Successful E-Learning? An Empirical Investigation of the Critical Factors Influencing Learner Satisfaction. Computers \& Education, 50(4), 1183-1202.

The report of world economic forum Redesigning Business Value \& A Roadmap to Sustainable Consupmtion. (2010). [Online]. Available: http://www.slideshare. net/sustainablebrands/wefredesigning-businessvalue

Tong, V.C.H. (2014). Towards Technology and Research-Enhanced Education (TREE): Electronic Feedback as a Teaching Tool in Geoscience. Geoscience Research and Education: Teaching at Universities. Innovations in Science Education and Technology, 20, 199-212. 